\title{
Electoral Distancing: Alternatif Penyelenggaraan Pemilihan Kepala Daerah 2020 Ditengah Covid-19 Di Indonesia
}

Putri Hergianasari*

Universitas Kristen Satya Wacana; putri.hergianasari@uksw.edu.

\section{A R T I C L E I N F O}

\section{Article history:}

Received 12-07-2020

Revised 30-07-2020

Accepted 25-08-2020

Key words:

Regional Head Elections, Electoral Distancing, Participatory Observers

\begin{abstract}
A B S T R A C T
The importance of Regional Head Election is carried out to keep democracy going even though we are doing that in the pandemic. The first objective of implementing this community service is to disseminate knowledge sharing and discussions related to the implementation of Regional Head Elections in the Covid-19 pandemic. Secondly, using the Electoral Distancing method, we are disseminating information to participants to oversee the Regional Head Election by becoming participatory supervisors actively. This community service used the online group discussion method with 65 participants, randomly selected from various activities. This community service aims to increase the capabilities of participants, which is related to the importance of implementing regional head elections even though it was carried out amid the Covid-19 pandemic. When participants became aware of this issue means there is an awareness for following health protocols without reducing the essence of democratic responsibility. By doing this works, we hope that the community continues to oversee the regional head elections by becoming participatory observers
\end{abstract}

\section{A B S T R A K}

Pentingnya pengabdian masyarakat ini dilakukan untuk mensosialisasikan pelaksanakan Pemilihan Kepala Daerah 2020 yang nota bene mengumpulkan massa di tengah situasi pandemi dan bagaimana menjaga demokrasi tetap berjalan. Tujuan pelaksanaan pengabdian masyarakat ini yang pertama, mensosialiasikan berbagi pengetahuan serta diskusi terkait pelaksanaan Pemilihan Kepala Daerah di tengah pandemi Covid19, yang mana pelaksanaan Pemilihan Kepala Daerah harus tetap dilakukan untuk menjaga kesinambungan demokrasi pada sistem presidensial termasuk pada pemerintahan lokal. Kedua, mensosialisasikan kepada peserta untuk aktif mengawal Pemilihan Kepala Daerah dengan cara menjadi pengawas partisipatif dengan electoral distancing. Pengabdian masyarakat ini menggunakan metode diskusi kelompok secara daring dengan 
peserta 65 orang yaitu mahasiswa dan umum. Hasil dari pengabdian masyarakat ini adalah peningkatan kapabilitas peserta terkait pentingnya pelaksanaan pemilihan kepala daerah walaupun dilaksanakan ditengah pandemi Covid-19, peserta menjadi paham bahwa pelaksanaan pemilihan kepala daerah dengan cara elektoral distancing dengan arti mengikuti protokol kesehatan dengan tidak mengurangi esensi dari pesta demokrasi, serta diharap masyarakat tetap mengawal pemilihan kepala daerah dengan menjadi pengawas partisipatif.

\section{PENDAHULUAN}

Pesta demokrasi Pemilihan Kepala Daerah atau yang lebih dikenal dengan Pilkada serentak di Indonesia diselenggarakan pada akhir tahun 2020 tepatnya yaitu pada tanggal 9 Desember 2020. Pemilihan lima tahunan ini merupakan sebuah kegiatan yang rutin dilakukan. Menjadi permasalahan pada Pemilihan Kepala Daerah 2020 karena diselenggarakan di tengah pandemi Covid-19 dimana pemerintah mengharuskan untuk melaksanakan social distancing dan physical distancing. Sementara itu, penyelenggaraan Pilkada syarat akan pengumpulan massa, yaitu dari mulai tahapan aktivitas penyusunan daftar pemilih, pencocokan data pemilih, penetapan bakal pasangan calon, tahapan kampanye, sampai dengan pemungutan suara. Hal ini juga berimplikasi dengan peserta pasangan calon untuk melakukan kampanye yang identik dengan mobilisasi politik agar mendapatkan dukungan pemilih untuk mendapatkan suara terbanyak (Hergianasari, 2016).

Untuk menyikapi hal tersebut Menteri Dalam Negeri, DPR, KPU, Bawaslu, dan DKPP sepakat menunda penyelenggaraan Pilkada 2020. Opsi penundaan Pilkada yaitu 9 Desember 2020, 17 Maret 2021 dan 29 Desember 2021. PP Nomor 2 Tahun 2020 kemudian menetapkan pilihan pertama yaitu 9 Desember 2020 sebagai tanggal pelaksanaan Pilkada 2020. Penetapan tanggal tersebut menimbulkan perdebatan karena pada bulan Agustus 2020 di Indonesia grafik kasus positif Covid-19 belum mengindikasikan adanya penurunan (Infografis COVID-19 (1 September 2020) Berita Terkini| Gugus Tugas Percepatan Penanganan COVID-19, n.d.)

Pandemi Covid-19 berdampak signifikan dan memberikan tekanan di berbagai wilayah negara untuk memutuskan apakah Pemilu atau Pilkada (di tingkat lokal) dapat berlangsung atau tidak sehingga hal tersebut menuai kontroversi. Dua pilihan yang dilematis yaitu pemenuhan kontrak sosial antara pemerintah dengan masyarakat atau meningkatnya kasus positif Covid-19 akibat dari berkumpulnya massa karena mengikuti Pilkada. (Spinelli, 2020). Data pada International IDEA (Institute for Democracy and Electoral Assistance) pada artikel yang berjudul "Global Overview of Covid-19: Impact on elections, menginfokan bahwa terdapat 50 wilayah dan negara yang sedang dihadapkan oleh potensi penyebaran Covid-19 akibat dari penyelenggaraan pemilihan baik Pemilu maupun Pilkada, oleh karena itu beberapa negara memutuskan untuk menunda penyelenggaraan pemilihan. Akan tetapi terdapat beberapa negara yang tetap menyelenggarakan pemilihan sesuai dengan jadwal yang telah ditetapkan.(Global Overview of COVID-19: Impact on Elections | International IDEA, n.d.). sebagai contoh yaitu negara Korea Selatan yang tetap menyelenggarakan pemilihan sesuai dengan jadwal. Sebagai salah satu 
negara yang pertama kali menyelenggarakan pemilihan di tengah pandemi Covid-19 dan pemilihan Korea Selatan menjadi perhatian publik dunia.

Langkah yang diambil Korea Selatan untuk meminimalisir resiko akibat penyelenggaraan pemilihan yaitu dengan cara melakukan tindakan yang luar biasa untuk keadaan yang luar biasa. NEC atau National Election Commission Korea Selatan mempunyai strategi yaitu menghalangi infeksi sebaik mungkin merupakan manajemen pemilu. Pertama, dengan mendorong pemungutan suara lebih awal, yaitu mendorong konstituen untuk melakukan pemungutan suara sebelum tanggal yang ditetapkan yaitu 15 April 2020, dengan metode mempersilahkan semua pemilih untuk memberikan suara di tempat pemungutan suara manapun walaupun tempatnya berjauhan dengan daerah tempat tinggal konstituen yaitu pemilihan sela pada tanggal 10 dan 11 April 2020. Tujuan dari strategi tersebut yaitu untuk mengurangi jumlah konstituen pada pemilihan tanggal 15 April 2020. Kedua, memperbolehkan melakukan pemungutan suara di rumah yaitu dengan melalui pos untuk pasien karantina atau isolasi mandiri. Akan tetapi konstituen dengan kategori tertentu yang dapat melaksanakan pemilihan di rumah. Ketiga, memastikan lingkungan sekitar aman dan higienis untuk tempat pemungutan suara. NEC memberlakukan protokol kesehatan Covid-19 secara ketat yaitu tindakan pencegahan dan perlindungan, dari mulai pembatasan antrian di luar Tempat Pemungutan Suara, pembatasan kerumunan di Tempat Pemungutan Suara, perlengkapan pemilu yang higienis. Strategi protokol kesehatan yang ketat tidak hanya berlaku untuk pemilih, akan tetapi berlaku untuk keseluruhan yaitu penyelenggara, pengawas, aparat keamanan, pemantau pemilu, media massa. Keempat, berkomunikasi dengan masyarakat melalui media elektronik maupun cetak untuk menyampaikan pesan tata cara pelaksanaan pemungutan suara. Kelima, tetap menjaga transparansi dalam proses pemungutan dan perhitungan suara yaitu dengan cara disiarkan secara langsung sehingga persiapan, proses, perhitungan, pemindahan dan penyimpanan surat suara dapat disaksikan secara online. Keenam, metode kampanye dengan memanfaatkan digitalisasi yaitu kampanye melalui media sosial, Argumen Reality (AR) yang berfungsi untuk berinteraksi secara jarak jauh dan virtual dengan massa pendukung calon.((PDF) Menyelenggarakan Pemilu Di Tengah Pandemi COVID-19: Ujian Krusial Republik Korea: Makalah Teknis International IDEA 2/2020, n.d.)

Permasalahan yang muncul yaitu ancaman terhadap keselamatan jiwa dan kesehatan masyarakat jika Pilkada 2020 tetap dilaksanakan, yang berdampak resiko bagi masyarakat sebagai konstituen, peserta yaitu pasangan calon dan penyelenggara Pilkada yaitu KPU dan tim. Tidak hanya itu, penurunan atau degradasi kualitas dari tahapan penyelenggaraan yang dilakukan di tengah pandemi Covid-19 berpotensi menimbulkan malpraktek dalam proses penyelenggaraannya, mulai dari pemutakhiran data pemilih, verifikasi syarat dukungan calon perseorangan, kampanye dan pemungutan suara. Partisipasi masyarakat untuk datang ke Tempat Pemungutan Suara (TPS) mengalami penurunan, partisipasi masyarakat sebagai relawan juga mengalami penurunan. Berdasarkan permasalahan-permasalahan tersebut di atas maka pentingnya pengabdian masyarakat ini dilakukan untuk memberikan pemahaman dan sosialisasi yaitu pentingnya menjaga demokrasi di tengah pandemi Covid-19. 
Pentingnya pengabdian masyarakat ini dilakukan yaitu untuk memberikan pemahaman, mendiskusikan dan mensosialisasikan berbagai pengetahuan terkait pelaksanaan Pilkada 2020 di tengah pandemi Covid-19, pelaksanaan Pilkada yang mana harus tetap dilaksanakan untuk menjaga kesinambungan demokrasi pada pemerintahan lokal. Selain itu, pentingnya pengabdian masyarakat ini dilakukan untuk mensosialisasikan kepada peserta untuk aktif mengawal Pilkada dengan cara menjadi pengawas partisipatif yang mana potensi adanya malpraktek di tengah Pandemi Covid-19 semakin meningkat.

Konsep dan teori yang mendukung penyelesaian masalah dalam pengabdian masyarakat ini antara lain adalah konsep partisipasi politik. Menurut Paul Sniderman dan Benjamin Highton dalam bukunya yang berjudul Facing the Challenge of Democracy Explorations in the Analysis of Public Opinion and Political Participation menyatakan bahwa warga negara atau citizens merupakan masyarakat yang mempunyai kemampuan berpolitik dan kehendak untuk berpolitik dengan sederhana hal tersebut merupakan ciri karakteristik pemilih pada umumnya. Bahkan ketidakkonsistenan pemilih juga merupakan permasalahan yang mendasar pada setiap pemilihan. Pemikiran politik publik tersebut dapat berpotensi penyebab polarisasi partai, motivasi partisipasi politik, serta hubungan yang paradoks antara jumlah pemilih dengan representasi demokrasi. Para pemilih atau konstituen hanya dapat melakukan pilihannya berdasarkan dengan alternatif yang ditawarkan. Alternatif tersebut juga dibatasi oleh pemain ketiga, yaitu kelompok kepentingan (interest groups).

Pemilih seringkali tampak berpandangan sempit, dan tidak konsisten dalam melakukan pemilihan. (Sniderman \& Highton, 2011) Sehingga hal tersebut merupakan tantangan demokrasi. Tantangan demokrasi yang sering terjadi tersebut ditambah dengan terjadinya pandemi global yaitu Covid-19 yang mana pelaksanaan Pilkada harus dengan menerapkan protokol kesehatan yaitu social distancing dan physical distancing. Partisipasi politik masyarakat sangat menentukan keberhasilan penyelenggaraan Pilkada 2020.

Keterlibatan masyarakat secara aktif untuk berpartisipasi pada proses Pemilihan Kepala Daerah baik sebagai pengguna hak pilih, melakukan pendidikan politik kepada sesama, membantu pengawasan pelaksanaan Pilkada, hal tersebut merupakan kontrol dari masyarakat atau publik untuk mengawal suara dan menjaga kedaulatan rakyat. Akan tetapi pada pelaksanaannya 2020 mengalami hal yang jauh berbeda karena adanya Covid-19. Larangan kegiatan yang mengumpulkan massa atau kerumunan tercantum dalam Maklumat Kapolri Nomor Mak/2/III/2020 diterbitkan pada 19 Maret 2020 dan dicabut dengan Surat Telegram Rahasia (TR) Kapolri Jendral Idham Azis nomor STR/364/VI/OPS.2/2020kemudian dapat dijadikan pedoman Komisi Pemilihan Umum Kabupaten/Kota sebagai penyelenggara untuk mengubah kegiatan yang dulunya tidak memperbolehkan kegiatan yang berpotensi mengumpulkan massa menjadi dibatalkan dan diubah dengan kegiatan yang baru yang memungkinkan mengadakan kegiatan akan tetapi dengan melaksanakan protokol kesehatan Covid-19. Hal tersebut merupakan tantangan bagi penyelenggara Pilkada untuk inovatif dalam melakukan tahapan pelaksanaan. (Ini Jadwal Lengkap Tahapan Pilkada Serentak 2020 Terbaru-Kabar24 Bisnis.Com, n.d.) 


\section{METODE PELAKSANAAN}

Pengabdian masyarakat ini dilakukan juga pada saat pandemi Covid-19 yaitu pada tanggal 17 Agustus 2020 sehingga lokasi pengabdian masyarakat ini yaitu melalui diskusi secara daring dengan menggunakan aplikasi Zoom dengan peserta mahasiswa dari Universitas Kristen Satya Wacana Fakultas Ilmu Sosial dan Ilmu Komunikasi, mahasiswa dari luar kampus UKSW, dan peserta umum dengan jumlah 65 orang. Kegiatan ini dilakukan dengan menggunakan metode penyuluhan, sosialisasi, FGD serta brain storming secara daring menggunakan Aplikasi Zoom karena di tengah pandemi Covid-19 yang mana harus menerapkan physical dan social distancing meminimalisir untuk mengumpulkan massa.

Panitia IRSA mengumumkan poster pengabdian masyarakat online pada media sosial yaitu WhatsApp group mahasiswa Hubungan Internasional tiap angkatan, Instagram IRSA, Instagram FISKOM, Instagram narasumber, Facebook FISKOM. Pendaftaran pengabdian masyarakat secara online melalui alamat http://bit.ly/3af7Dwc-WebinarHIdengan tahapan kegiatan yaitu pemaparan materi dan diskusi serta tanya jawab.

Pemaparan materi Pilkada di tengah pandemi Covid-19, yaitu pertama menjelaskan gambaran umum penyelenggaraan Pilkada 2020 serta daerah yang menyelenggarakan Pilkada yang terdiri dari 9 daerah melakukan pemilihan gubernur, 224 daerah melakukan pemilihan bupati, 37 daerah melakukan pemilihan walikota. Kedua, ketentuan pelaksanaan Pilkada yaitu penundaan Pilkada yang seharusnya diselenggarakan September menjadi Desember 2020. Ketiga, penundaan tahapan pilkada. Keempat, potensi permasalahan yang timbul, kelima, prinsip pelaksanaan Pilkada di tengah pandemi Covid-19, keenam, penutup.

\section{HASIL DAN PEMBAHASAN}

Pengabdian masyarakat ini menghasilkan alternatif tata cara penyelenggaraan Pilkada di tengah Covid-19 dengan nama tata cara yaitu "Electoral Distancing" yang mana mengkolaborasikan prinsip pelaksanaan Pilkada di tengah Covid-19 oleh Bawaslu dengan tata cara penyelenggaraan Pilkada Korea Selatan 2020. Yaitu dapat dilihat pada tabel 1 .

Tabel 1. Electoral Distancing sebagai Alternatif Tata Cara Pelaksanaan Pilkada di Tengah Covid-19

\begin{tabular}{lll}
\hline NO & ASPEK/BIDANG & \multicolumn{1}{c}{ KETERANGAN } \\
\hline 1 & Kesehatan & $\begin{array}{l}\text { Perlindungan keamanan serta kesehatan yang maksimal terhadap } \\
\text { semua pihak yang terlibat dalam pelaksanaan Pilkada mulai dari hulu } \\
\text { sampai hilir tahapan Pilkada }\end{array}$ \\
& Ketersediaan kerangka hukum yang adaptif serta akuntabel dalam \\
& pelaksanaan Pilkada. "Kerangka hukum yang pro pada keamanan \\
dan kesehatan semua pihak" & Dukungan anggaran dan logistik yang tepat waktu. "Di setiap TPS \\
& disediakan masker, hand sanitizer dan sarung tangan \\
& komitmen semua pihak untuk menjaga keberlanjutan tahapan Pilkada \\
& yang jujur, adil, dan demokratis walaupun di tengah pandemi. Tidak \\
& Komitmen & ada diskriminasi antara paslon satu dengan paslon yang lain.
\end{tabular}




\begin{tabular}{|c|c|c|}
\hline NO & ASPEK/BIDANG & KETERANGAN \\
\hline & & $\begin{array}{l}\text { Penegakan integritas, kredibilitas, transparansi dan akuntabilitas hasil } \\
\text { Pilkada }\end{array}$ \\
\hline 5 & Politik & $\begin{array}{l}\text { Situasi politik yang kondusif membuat berbagai aktor dan pemangku } \\
\text { kepentingan dapat menerima dengan baik terkait pembatasan pada } \\
\text { aktivitas kampanye tradisional (konvensional) akibat Covid-19 }\end{array}$ \\
\hline 6 & Sarana dan Prasarana & $\begin{array}{l}\text { Ketersediaan untuk membangun kondisi pemungutan suara yang } \\
\text { aman dan sehat }\end{array}$ \\
\hline 7 & Politik & $\begin{array}{l}\text { Stabilitas politik dalam negeri yang dapat membuat berbagai aktor } \\
\text { politik dan pihak-pihak yang berkepentingan dalam pemilihan } \\
\text { bersedia menerima dengan lapang hati berbagai pembatasan aktivitas } \\
\text { kampanye konvensional akibat pandemi Covid-19. Stabilitas politik } \\
\text { dalam negeri yang kondusif berarti berdampak pada percaturan } \\
\text { politik yang seimbang sehingga dapat menciptakan kesempatan dan } \\
\text { peluang bagi seluruh partai politik dan calon. }\end{array}$ \\
\hline 8 & Pengawas Partisipatif & $\begin{array}{l}\text { Penerapan protokol kesehatan, masyarakat diharap ikut mengawal } \\
\text { pesta demokrasi yaitu sebagai konstituen sekaligus sebagai pengawas } \\
\text { partisipatif, serta menjaga transparansi dalam proses pemungutan } \\
\text { serta perhitungan suara }\end{array}$ \\
\hline 9 & Sinergitas & $\begin{array}{l}\text { Peran sinergitas antara penyelenggara Pilkada yaitu KPU, calon } \\
\text { peserta Pilkada, konstituen, Bawaslu, Polri, petugas kesehatan dan } \\
\text { pihak-pihak terkait dalam keberlangsungan pemilihan dengan } \\
\text { penerapan protokol kesehatan secara ketat }\end{array}$ \\
\hline
\end{tabular}

Dari tabel 1 tersebut merupakan rekomendasi pelaksanaan Pilkada di tengah pandemi-Covid-19 yang disebut electoral distancing. Presiden Joko Widodo memberikan arahan untuk penyelenggaraan Pilkada 2020, berikut bagan arahan Presiden Joko Widodo.
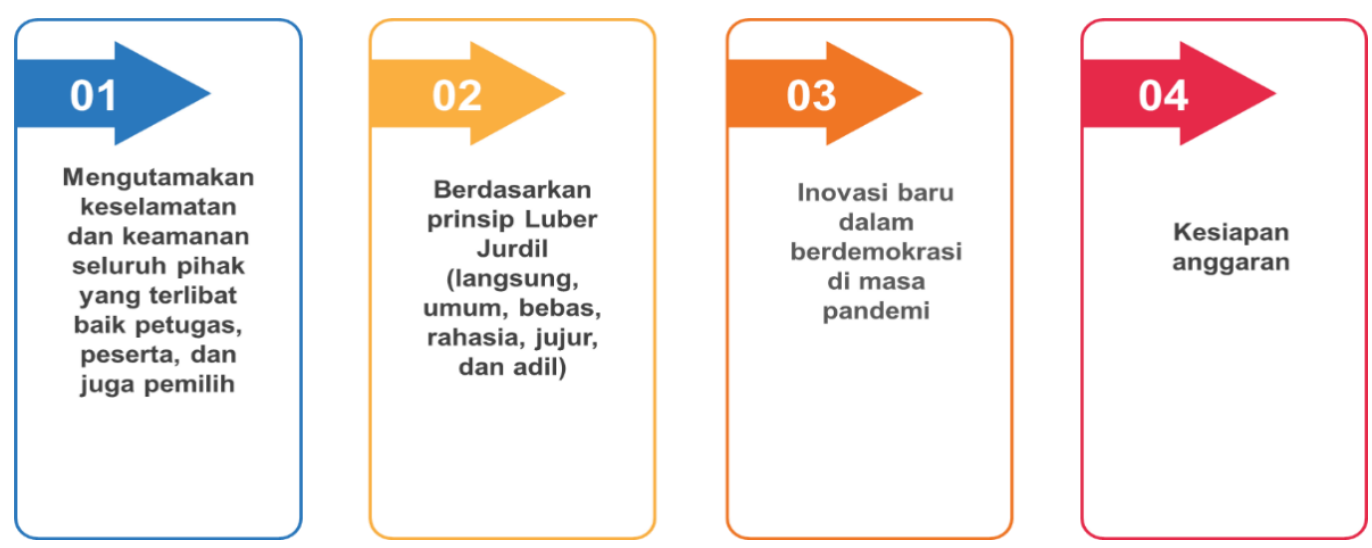

Gambar 1. Arahan Penyelenggaraan Pilkada Serentak 2020

Bagan tersebut merupakan arahan penyelenggaraan Pilkada serentak 2020 oleh Presiden Joko Widodo agar pelaksanaan mengutamakan keselamatan dan keamanan seluruh pihak baik dari petugas, panitia, peserta serta pemilih. Walaupun banyak batasan-batasan yang harus dilaksanakan.

Hasil pengabdian masyarakat ini adalah tercapainya penyuluhan dan sosialisasi terkait pemaparan edukasi kepada peserta dengan hasil capaian adalah jumlah sasaran 65 orang sesuai dengan pendaftaran dan pemaparan edukasi 
pentingnya menyelenggarakan Pilkada di tengah pandemi Covid-19 dengan wajib melakukan electoral distancing. Selain itu pentingnya mengawal Pilkada untuk menjadi pengawas partisipatif. Hasil capaian kegiatan pengabdian masyarakat yaitu dapat dilihat pada antusiasme peserta dalam diskusi tanya jawab yang disajikan pada tabel 2.

Tabel 2. Capaian Diskusi Kegiatan Pengabdian Masyarakat

\begin{tabular}{|c|c|c|c|}
\hline No & Nama Peserta & Pertanyaan & Tanggapan \\
\hline & $\begin{array}{l}\text { Dr. Wilson Therik } \\
\text { (Dosen Interdisipliner } \\
\text { UKSW) }\end{array}$ & Bagaimana dengan e-voting? & $\begin{array}{l}\text { Kesiapan KPU } \\
\text { penyelenggaraan Pilkada secara } \\
\text { online dengan e-vote belum siap, } \\
\text { akan tetapi verifikasi data secara } \\
\text { online sudah dilakukan }\end{array}$ \\
\hline & $\begin{array}{lr}\text { Imanuel } & \text { Gerson } \\
\text { (mahasiswa } & \text { HI } \\
\text { FISKOM UKSW) } & \end{array}$ & $\begin{array}{l}\text { Adakah pengaruh Covid-19 } \\
\text { terhadap tingkat kepercayaan } \\
\text { masyarakat dalam Pilkada } \\
\text { kepada calon pemimpin } \\
\text { daerah? Terutama di daerah } \\
\text { Timur yang notabene jaringan } \\
\text { internet di sana sulit untuk } \\
\text { dijangkau. Melihat salah satu } \\
\text { tantangan dalam Pilkada yaitu } \\
\text { para calon sulit untuk } \\
\text { berkampanye }\end{array}$ & $\begin{array}{l}\text { Hal tersebut merupakan tantangan } \\
\text { bakal calon untuk mendapatkan } \\
\text { simpati masyarakat. Oleh karena } \\
\text { itu tema kampanye bantuan } \\
\text { logistik ataupun program-program } \\
\text { penanganan Covid-19 menjadi isu } \\
\text { yang strategis untuk diangkat } \\
\text { sebagai topik kampanye }\end{array}$ \\
\hline & $\begin{array}{l}\text { Imaniar (Mahasiswa } \\
\text { HI FISKOM) }\end{array}$ & \begin{tabular}{lr} 
Karena & \multicolumn{2}{r}{ Covid-19 } \\
mengakibatkan para calon \\
kesulitan untuk kampanye, \\
bagaimana menyikapi hal \\
tersebut?
\end{tabular} & $\begin{array}{l}\text { KPU telah melonggarkan } \\
\text { kampanye pada media elektronik, } \\
\text { sehingga kampanye dapat di } \\
\text { disiarkan di TV sebagai iklan, } \\
\text { siaran di TV debat pasangan calon, } \\
\text { melalui media sosial dan baleho } \\
\text { dan spanduk yang dipasang di } \\
\text { daerah-daerah strategis }\end{array}$ \\
\hline & $\begin{array}{l}\text { Falah (Peserta Umum } \\
\text { dari Aceh) }\end{array}$ & $\begin{array}{l}\text { Mengapa pemerintah tetap } \\
\text { menjalankan Pilkada di tengah } \\
\text { pandemi Covid-19 }\end{array}$ & $\begin{array}{l}\text { Untuk tetap menjaga } \\
\text { kesinambungan demokrasi agar } \\
\text { tidak terjadi kepemimpinan yang } \\
\text { otoritarian dengan memanfaatkan } \\
\text { situasi pandemi Covid-19. }\end{array}$ \\
\hline
\end{tabular}

\section{SIMPULAN}

Dampak dari pengabdian masyarakat diperoleh yaitu peningkatan kesadaran masyarakat terhadap urgensi Pemilihan Kepala Daerah tetap diselenggarakan di tengah pandemi Covid-19 karena dengan berpartisipasi dalam memberikan suara maka ikut serta menjaga kesinambungan demokrasi. Peningkatan kesadaran masyarakat akan pentingnya menjadi pengawas partisipatif. Karena penyelenggaraan Pilkada akan berjalan dengan baik pada setiap tahapannya apabila mendapat pengawasan dan dukungan dari masyarakat. Sehingga pengabdian masyarakat ini juga memberikan solusi alternatif tata cara penyelenggaraan Pemilihan Kepala 
Daerah di tengah pandemi Covid-19 dengan cara electoral distancing yang diusulkan kepada Komisi Pemilihan Umum.

Prinsip electoral distancing harus dipedomani sebagai tindakan pencegahan penularan virus. Menjaga jarak fisik dan mencegah kontaminasi objek oleh orang yang terinfeksi, sanitasi tangan, pemakaian masker, dan alat pelindung diri (APD), harus menjadi bagian penting dari tata cara selama Pilkada. Tata cara ini harus disosialisasikan kepada seluruh stakeholder Pilkada dan menjadi materi pendidikan pemilih. Penggunaan media sosial adalah adaptasi atas perubahan zaman di mana masyarakat lebih sering mengakses media daring daripada media konvensional. Serta pentingnya peran pengawasan electoral distancing partisipatif oleh masyarakat

\section{DAFTAR PUSTAKA}

(PDF) Menyelenggarakan Pemilu Di Tengah Pandemi COVID-19: Ujian Krusial Republik Korea: Makalah Teknis International IDEA 2/2020. (n.d.). Retrieved August 31, 2020, from https://www.researchgate.net/publication/ 340838384_Menyelenggarakan_Pemilu_Di_Tengah_Pandemi_COVID-19_ Ujian_Krusial_Republik_Korea_Makalah_Teknis_International_IDEA_22020

Global overview of COVID-19: Impact on elections | International IDEA. (n.d.). Retrieved August 31, 2020, from https://www.idea.int/news-media/multimediareports/global-overview-covid-19-impact-elections

Hergianasari, P. (2016). MATINYA MESIN PARTAI POLITIK (Studi Kasus Pencalonan Syahri Mulyo dalam Pilkada Kabupaten Tulungagung 2013). In Jurnal Cakrawala ISSN (Vol. 1693, Issue 2). https://ejournal.uksw.edu/ cakrawala/article/view/668

Infografis COVID-19 (1 September 2020) - Berita Terkini| Gugus Tugas Percepatan Penanganan COVID-19. (n.d.). Retrieved September 2, 2020, from https://covid19.go.id/p/berita/infografis-covid-19-1-september-2020

Ini Jadwal Lengkap Tahapan Pilkada Serentak 2020 Terbaru - Kabar24 Bisnis.com. (n.d.). Retrieved August 29, 2020, from https://kabar24.bisnis.com/read/ 20200624/15/1257129/ini-jadwal-lengkap-tahapan-pilkada-serentak-2020terbaru

Sniderman, P. M., \& Highton, B. (2011). Facing the challenge of democracy: Explorations in the analysis of public opinion and political participation. In Facing the Challenge of Democracy: Explorations in the Analysis of Public Opinion and Political Participation.

Spinelli, A. (2020). Menyelenggarakan Pemilu Di Tengah Pandemi COVID-19: Ujian Krusial Republik Korea: Makalah Teknis International IDEA 2/2020. In Menyelenggarakan Pemilu Di Tengah Pandemi COVID-19: Ujian Krusial Republik Korea: Makalah Teknis International IDEA 2/2020. International Institute for Democracy and Electoral Assistance (International IDEA). https://doi.org/10.31752/idea.2020.17 


\section{LAMPIRAN}

Foto 1: Poster Pengabdian Masyarakat

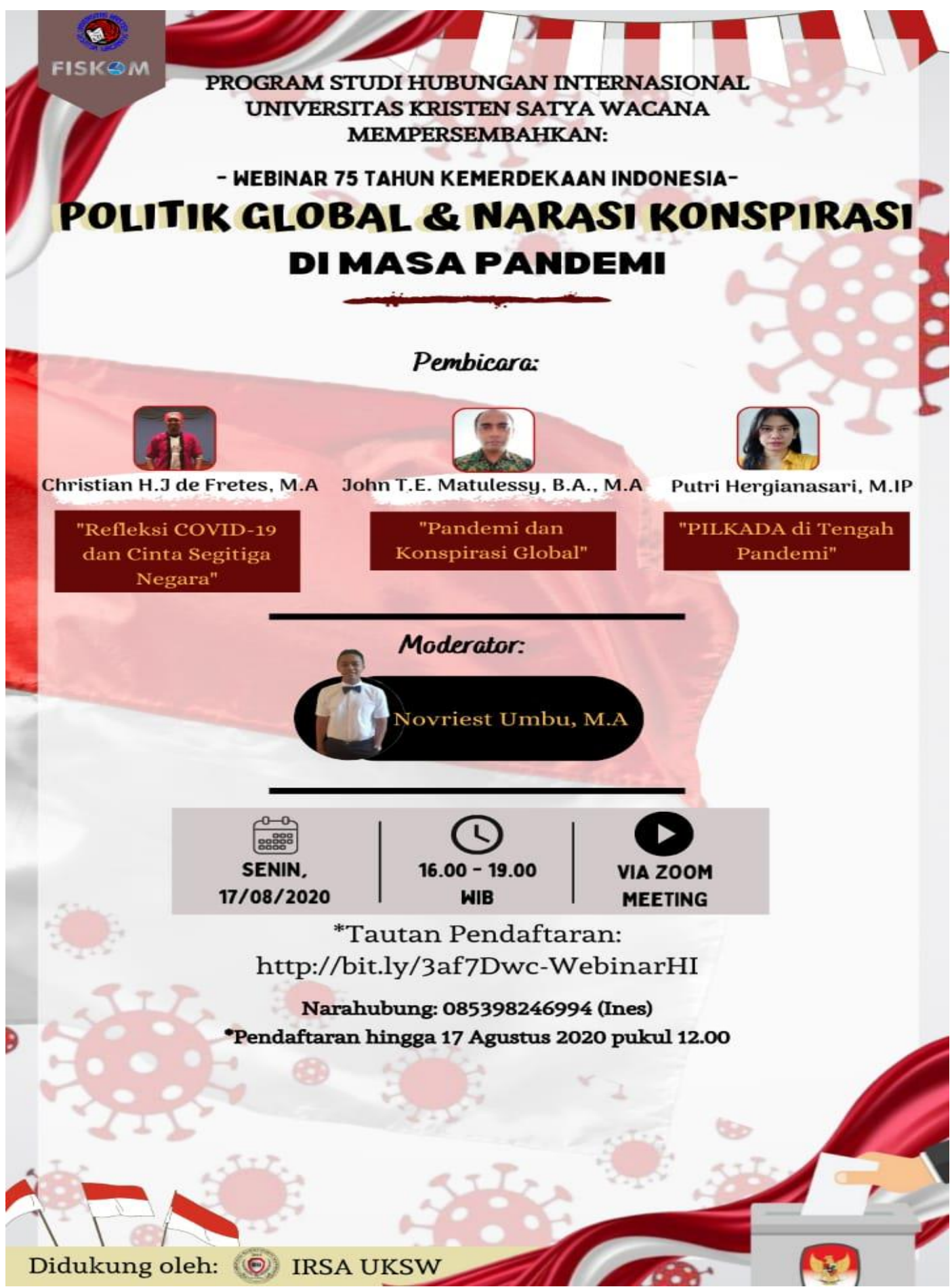


Foto 2: Foto Kegiatan Pengabdian Masyarakat

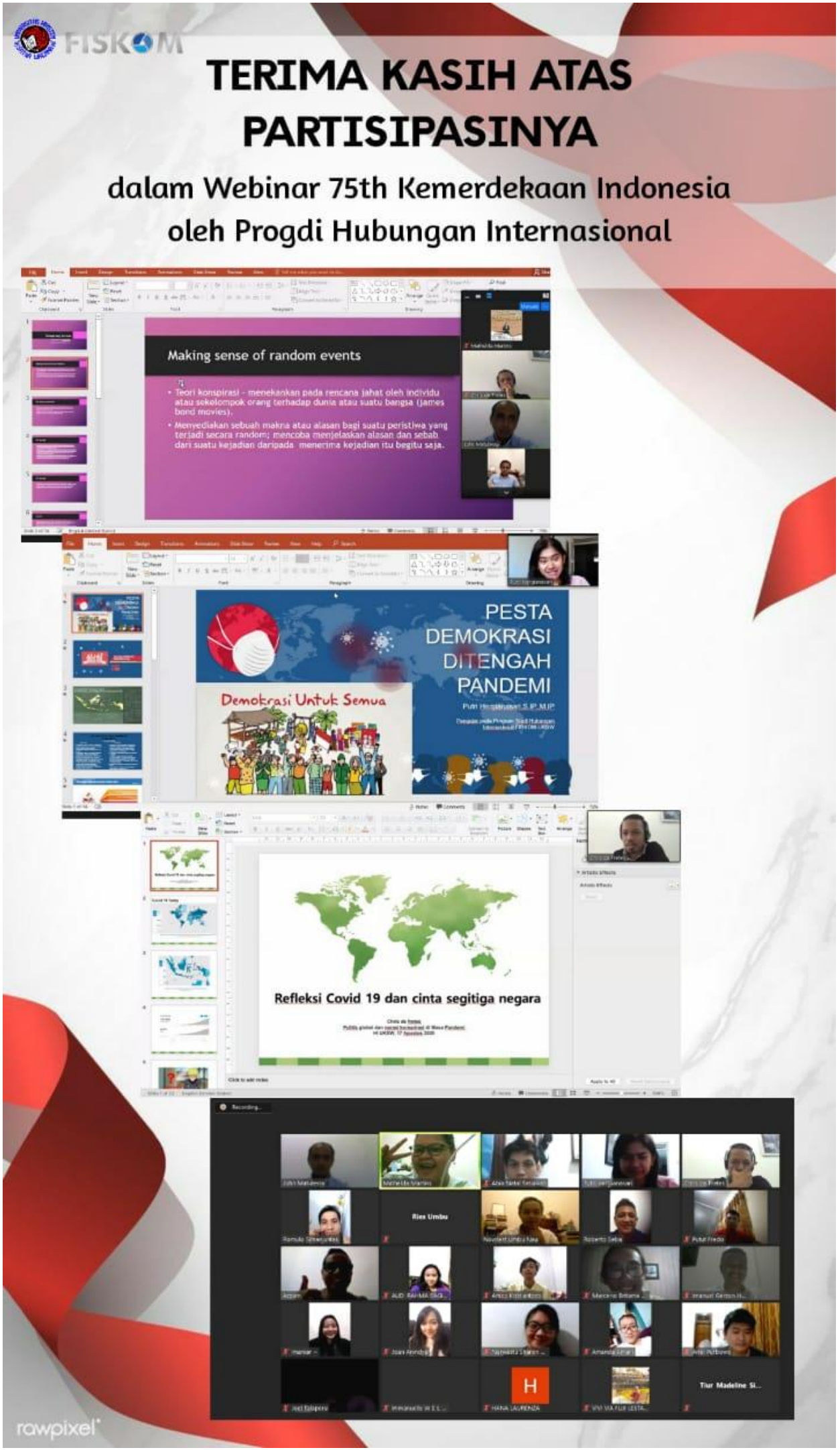

